\title{
Duluth to Liverpool in One Bottom
}

The Arguments Advanced in Favor of a Deep-Water Route Between the Great Lakes and the Sea

By Robert G. Skerrett

THE measure of our productiveness, the prompt distribution of our multi-
ple commodities, and the satisfying of a restless public, hinge in large measure upon the expeditious movement of our tremendous and steadily increasing volume of freight. The tide of this traffic is today distressingly slowed up by reason of the demoralized condition of our railways, and it is inevitable that we find other means of distribution so that the tide of foreign and domestic comthe tide of foreign and domestic com-
merce may be brought to a state of equi-

merce may
librium.

We cannot achieve this rital end-a goal which is profoundly linked with the nation's well being-unless we bring the vast industrial areas of the West and the Middle West within easier touch of the seaboard. The citizenry of other divisions of the country seldom realize the ecoof the country seldom realize the eco-
nomic significance of the States bordering upon or tributary to the Great Lakes. In certain phases of agriculture, meat packing, dairy products, manufactures, and mineral yields, the total for the United States six years ago amounted to $\$ 29,398,414,000$, while the group of interior States just referred to furnished nearly 40 per cent of this magnificent sum. And this is only the beginning of the nificent sum. And this is only the beginning of the story: a few of the details will make it
much of a treasure house this region much of a treasure house this region
really is. Occupying but one-third of the national area, its wide-awake population produces something like seven-eightlss of our principal staples, exclusive of cot ton and tobacco. Upon its fertile fields are 75 per cent of our wheat; 65 per cent of our corn; substantially all of our flar. half of our potatoes and sugar beets; 50 her cent of the country's cattle, dairy per cent of the country's cattle, dairy
cows, and swine; 60 per cent of our horses. From the mines in these States come 85 per cent of our iron; 39 per cent of our copper ; 74 per cent of our zinc; 46 per cent of our lead. And the geologists tell us that quite 72 per cent of our measured coal reserves lie within this favored zone.

The stimulus of the recent confiict did much to augment many of the foregoing figures; and now as a people we must either help ourselves by helping those States to continue at their present productive pace or we shall have to see them slump as a source of stupendous economic power. In a large sense the future of this section and the welfare of all of us depend upon the Great Lakes being opened to the sea so that ocean-going craft can steam from Duluth to the Atlantic and thence along our neighboring seaboard or afar to the markets of Europe. A deep-water route of this character, ample enough to float laden craft of drafts from 20 to 25 feet, would accommodate 25 feet, would accommodate the great majority of the existing ocean steamships.
This splendid project has This splendid project has during the past two decades and more, and the probable cost would be trifing in comparison with the immeliate and prospective benefits to be realized. Indeed, the entire outlay for us, inthe entire outlay for us, in-
cluding the deepening of cluding the deepening of
present channels through the Great Lakes and tributary to the cities thereon, would probably not equal one-fourth the sum we gladly subscribed to build the Panama Canal; and the gains in some respects gains in some respects
would be much bigger at the very start than those

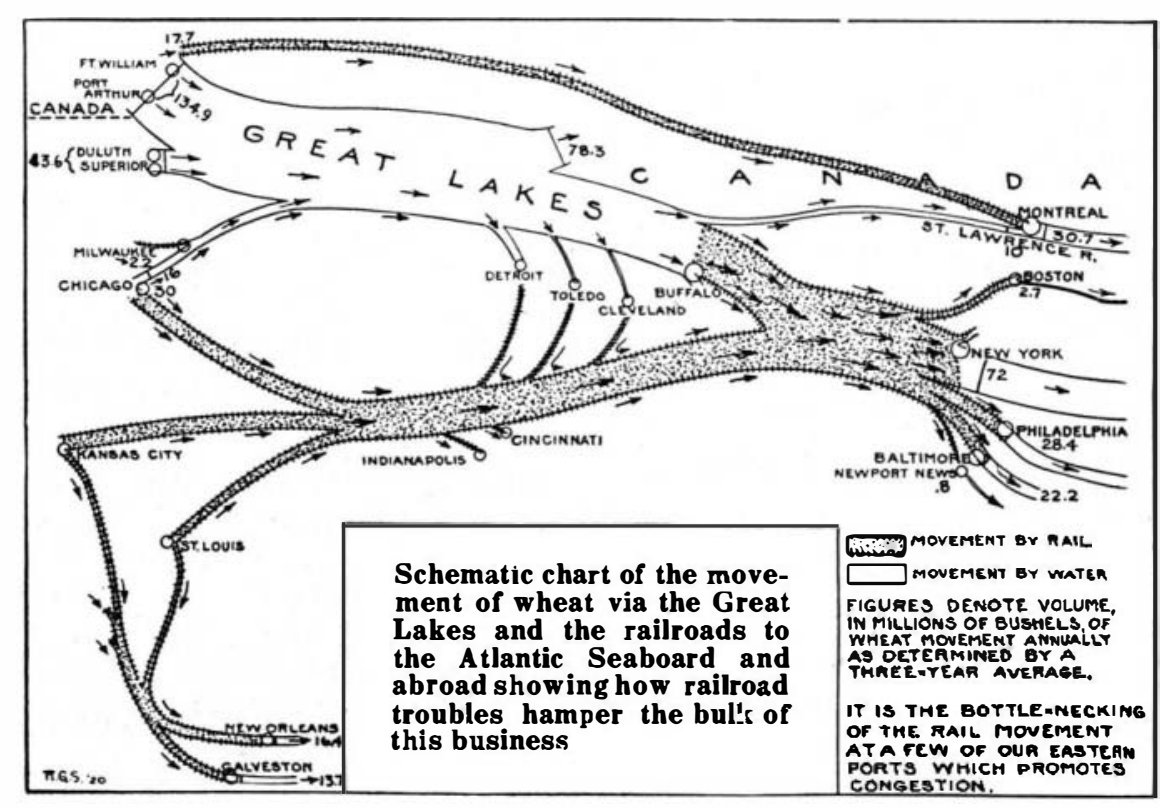

volve, incidentally, the work of flooding the Lachine Rapids.

Today the Canadians are enlarging the Welland Canal so that the roomiest locks will be 1,000 feet long, 80 feet wide, and have a depth of 30 feet of water at the lowest level of the river. This work was slowed up by the war, but is now being pushed energetically and should be finished in the course of four years at a total expenditure of $\$ 75,000,000$. From Galop Rapids to St. Regis, a distance of about $\mathbf{1 1 5}$ miles, the St. Lawrence drops 92 feet, and sufficient water for deepdraft ressels can be obtained by building across the international stream a series of dams which would convert the areas now occupied by rapids into a number of navigable slack-water basins. In these dams there would be formed numerous locks so that steamers bound up or down could thus pass from level to level whil threading the broad channel of the modified St. Lawrence.

From St. Regis on to Montreal, a run of 68 miles, the St. Lawrence has a fall

now reaped by us through the agency of the Isthmian waterway. Thanks to the enterprise of neighboring Canada, the problem broadly reduces itself to submerging certain rapids lying in the international are now plain sailing with plenty of deep water. The engine pluin sailng with plenty of deep water. The dams at suitable points across the river to flood the hallows and rapids in about 22 miles of travel. This part of the scheme would rest upon Can ada, inasmuch as that section of the river lies wholly within her domain. The river will not be canalized in the usual sense of the term; the submerged rapids would afford broad channelways along which steamers could proceed at full wheed. Traftic would be slowed down only when using the canals interposed beonly when using the canals interposed between Lake Superior and Lake Ontario
or when changing level in going through or when changing level in going through
any of the locks. This celerity of movement will mean much toward making it profitable to operate ocean-going freighters over the projected route.

In June of last year, the Lake Grandby, an American freighter, 251 feet long. $431 / 2$-foot beam, and of 1,605 net tonnage, sailed from Chicago with a cargo of meat destined for Liverpool. She was the first of a fleet of 15 craft built by the United States Shipping Board and intended for this traffic. However, because the St. Lawrence canals now limit the draft to 14 feet, the Lake Grandby cannot start from her Lake port full laden-she takes on more cargo at Montreal. This means waters of the St. Lawrence River between Lake Ontario and the Indian village of St. Regis, and then dealing in a similar way with that stretch of the river extending from St. Regis to Montreal, which would in-

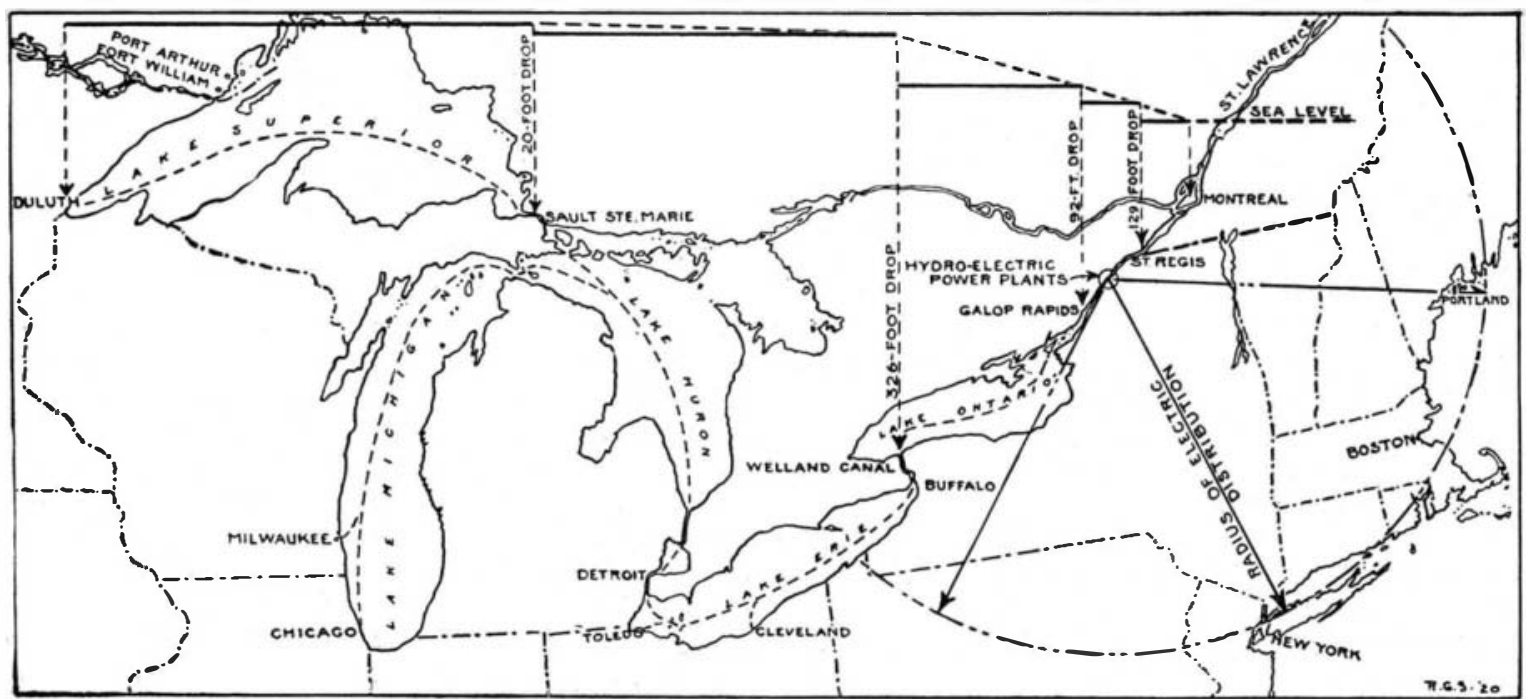

Map showing how a deep-water route from the Great Lakes to the Atlantic Ocean via the St. Lawrence River would shorten a voyage to Great Britain or Northern Europe by quite 500 miles and yield hydro power for distribution over a wide radius from the dams that when returning from abroad she must also discharge part of her freight at the Canadian port in order that she may steam on to Chicago. IVith the enlarged Welland Canal available, and with the contem plated dams and their great locks built, big cargo carriers of many thousands of tons could traverse the whole length of the St. Lawrence to and from Lake Erie; and with improve facilities at the Soo and deeper channels through the Lakes here and there, kee, Chicago, Detroit, Toledo, Cleveland, Buffalo, etc., would have an unhampered outlet to the ocean. As those familiar with the subject know, vessels laden with wheat bound from Duluth, Chicago, etc., Buffalo, and the grain is then dispatched by rail or canal to New York, Boston, and Philadelphia on its journey to consignees over(Continued on page 686) 


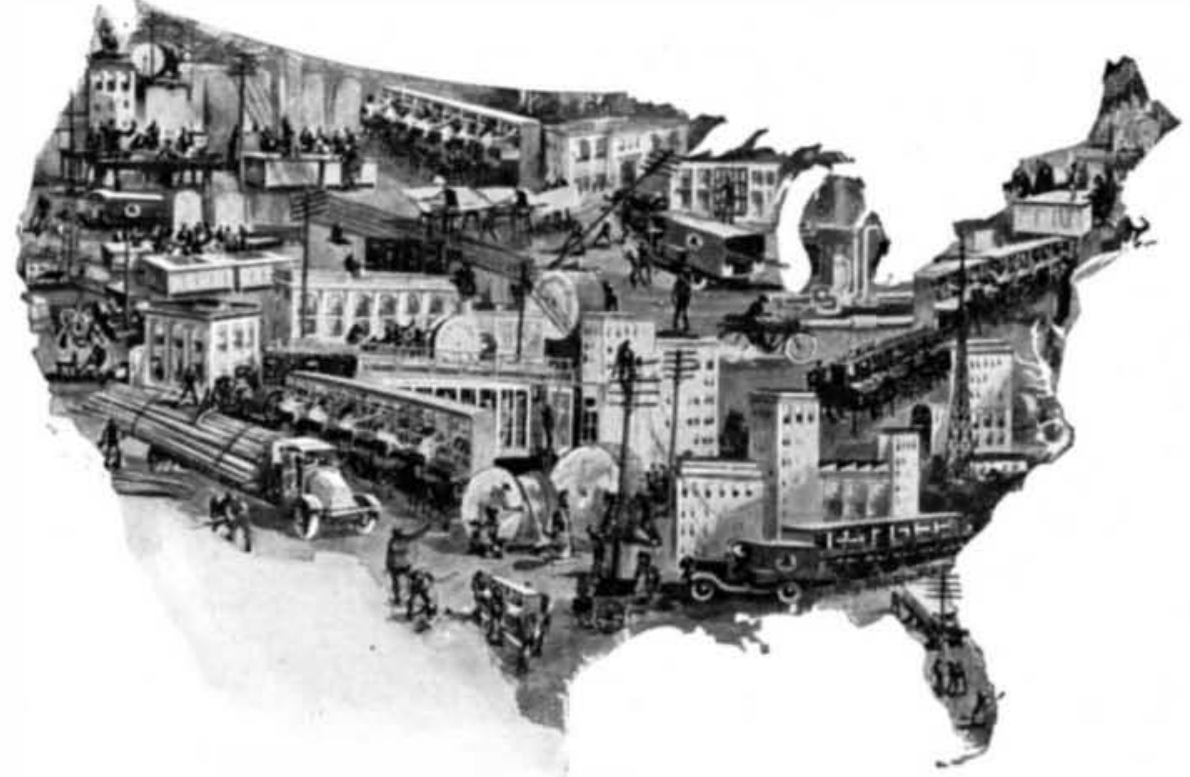

The laborer is worthy of his hire

All service is worthy of its hire and good service cannot be continuously obtained unless adequately rewarded.

From the beginning of telephone history the American public has received the best telephone service of any country in the world. In proportion to the service rendered the people have paid less for this telephone service than any other country in the world.

The reason why the American people have received the highest type of telephone service at the least proportionate cost is because the Bell System has been operated on a scientifically economic basis.

Every device which inventive skill, engineering ability, labor and time saving talent has been able to create; every efficiency known to buying, operation, executive control and financial conduct has been employed.

Public service companies feel the high cost of living as well as individuals. Pay them enough to make possible their giving good service. There is no permanent saving in poorly paid service.

In this land of opportunity none of us is willing to jeopardize his success or happiness by stinting the payment necessary to secure the most helpful and efficient service.

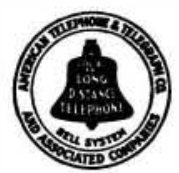

AMERICAN TELEPHONE AND TELEGRAPH COMPANY AND ASSOCIATED COMPANIES

One Policy One System Universal Service SOUTH BEND LATHES |For Gunsmiths, Tool Makers, ExFor the Machine perimental \& Repair Work, etc.

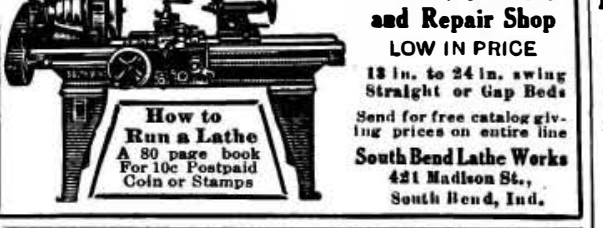

THE SCHWERDTLL STAMP CO. STEEL STANPS LETIERS \& FIGURES BRIDGEPORT CONN

\section{WELL ${ }_{\text {PAYS }}^{\text {DRIING WELL }}$}

Own a machine of your own. Cash or easy
terms. Many styles and sizes for all putrposes Write for Circular.

WULAMS BROS., 434 W. State St., Ithaca, N.Y.

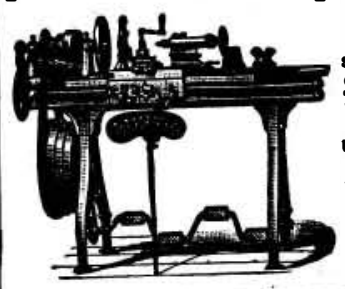

From 9-in. to 18-in. swing. Arranged for Velocipede or Standup Treadle.

W. F. \& J. Barnes C Established 1872. 1999 Ruby Street
Rockford, III.
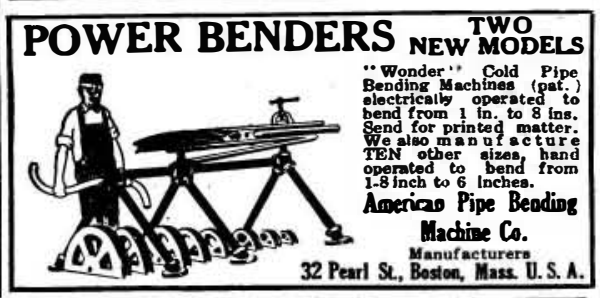

Now Ready! $A$ New Book on a New Subject

BEHIND THE MOTION-PICTURE SCREEN

By Austin C. Lescarboura

H $\mathrm{HRE}$, at last, is the wonder book of the scruen. It takes the reader into that marvelous land where films

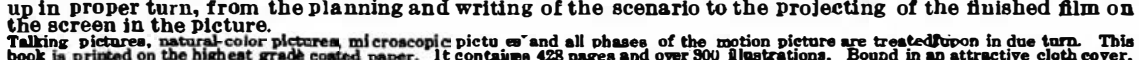
Sige $61 / 4 \times 91 / 2,33.50$; postage-15c in the East, aco to Chicago, 300 to the coas

One of the Most Attractive Booke Ever lesmed

SCIENTITr. AMERICAN PUBUSHING COMPANY
Duluth to Liverpool in One Bottom (Continued from page 670)

seas. This entails not only much additional handling, but it involves a good deal of increased expense. If ships could load on the Great Lakes and steam thence to their destinations across the Atlantic without further to-do, under normal conditions grain could be landed in Liverpool, for instance, for five cents less a bushel.

According to the engineering estimates, our part of the proposed undertaking would not involve an outlay of more than $\$ 60,000,000$ on the St. Lawrence, and $\$ 100,000,000$ would cover that work as well as the necessary channel and canal improvements needful to provide ample passageways for sea-going freighters trading with every first-class port on the Great Lakes. This sum does not loom large if we bear in mind that the State of New York has already spent on its barge canal system a matter of quite $\$ 150,000,000$. But other material benefits of an economic nature would accrue to us through our participation in the damming of the St. Lawrence. The outpouring waters from the enormous reseroirs of the Great Lakes would furnish our side of the St. Iawrence with motive force capable of developing substantially $1,000,000$ horsepower of electrical energy. Converted into terms of coal burned in steam generating plants, this water-developed power would represent each twenty-four hours a saving of 36,000 tons of fuel. Changing our potential million horsepower into electrical units we have 750,000 kilowatts, which at Niagara Falls rates of $\$ 20$ per kilowatt-year would produce a yearly revenue of $\$ 15,000,000$. If coal were burned to develop continuously so large a block of energy, the cost in the course of a twelvemonth would mount to $\$ 65,700,000$.

The hesitating taxpayer may be inclined to ask: "Do we really want this volume of potential horsepower--do we need it?" Census figures covering the period between 1889 and 1917 should satisfy the doubter and, at the same time, point to what will certainly be required in the course of the next five or ten years. The installed capacity of prime mover in central stations, manufacturing establishments, and the power plants of electric railways throughout New Englan and New York State amounted in 1900 to $12,270,000$ horsepower. By 1910 this total had reached 21,200,000 borsepower, and today the aggregate of these plants represents fully $27,200,000$ horsepower. By 1925 this great industrial region will need installations totalling $30,100,000$ horsepower, and ten years from now, at the present rate of increase, installations will be called for capable of a maximum debe borne in mind that this array of ures does not include the horsepower locomotives and thousands of isolated steam plants now meeting the demands of widely varying services. widely varying services.
It is true, of course, that navigation be tween the Great Lakes and the Atlantic tween the Great Lakes and the Atlantic
would be halted during four months of the winter period, but during the eight months remaining a tremendous tonnage could be moved via this route to and from our intensely productive interior section. The immediate and the reflex economic gains due to this new highway of commerce cannot be comprehensively evaluated in mere dollars and cents. In the winter time, many of the ships that might be employed in the Great Lakesocean trade could shift their activities to the Atlantic seaboard. The project in its entirety reasonably promises to deal with the peak-load period of seasonal freights and to lend itself potentially to the general stabilizing of our internal traffic system. Incidentally, it will promote the upbuilding of vast stretches of territor and bring in its train social, industrial, and economic readjustments of primary importance to the whole country.
LEGAL NOTICES PATENTS

IF YOU HAVE AN INVENTION 1 which you wish to patent you can Co for advice in regard to the best way of obtaining protection. Please send sketches or a model of your invention and a description of the device, explaining its operation.

All communications are strictly confidential. Our vast practice, extending over a period of seventy years, enables us in many cases to advise in regard to patentability without any expense to the client. Our HandBook on Patents is sent free on request. This explains our methods,

terms, etc., in regard to Paten
Trade Marks, Foreign Patents, etc.

SCIENTIFIC AMERICAN contains Patent Office Notes. Decisions of centlys to inventors-and on

MUNN \& CO., SOLPUTYNB Woolworth Building, CHICAGO, III
Tower Building,

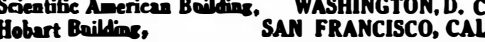

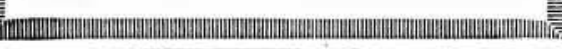

Annual Subscription Rates

Scientific American Publications Scientific American (established 1845) one
year $\ldots \ldots \ldots \ldots \ldots \ldots \ldots \ldots \ldots \ldots \ldots \ldots \ldots \ldots \ldots$ Scientific . American Monthily (established $\$ 5.00$

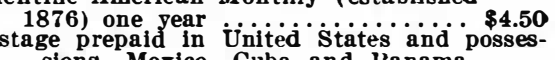

sions, Mexico, Cuba and l'anama. Foreign Postag.

Scientific American $\$ 1.50$ per year addutional.

ditional. Canadian Postage

Scientific American 75c per year additional.
Scientific American Monthly $36 \mathrm{c}$ per year additional. foreign countries including Canada, will be Remit by postal or express money order, bank

Classified Advertisements Advertising in this column is $\$ 1.00$ a line. accepted. Count seven words to the line. All BUSINESS OPPORTUNITIES SUBSTANTIAL Manufacturing Corporation wants
capable men to establish branch and manage salesmeet.
\&300 to 81500 necesgry more as explained. Address, Treasurer, 416 N. Howard
St.. Baltimore PATENT FOR SALE PATEN'r No, 1,335,707 for sale, covering "Electric
Alarm System," filvention giving Alarm at Teleph.ne Address at Yol, whent telepholle wires are cut or broken. PARTNER WANTED HAVE large European experlence in manufacture of
artistic wooden toys. Have flinest samples and patent-
able toys. W'ant a partner with nonoy to start a buslable of hilghest character or conneection with a toy
factory. Address, G.V. Adamec, East Tawas, Mich. FOR SALE

NEW JERSEY deposit of high grade Infusorial
Earth Address Pierre F. Cook, 1 Exchange Place, $\frac{\text { HELP WANTED }}{\text { Jersey City, N. J. }}$ PATENT Office Draftsman. State experience and
salary desired. Munn \& Co., 233 Broadway, New York

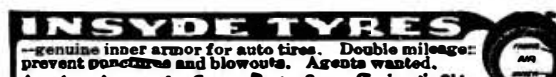

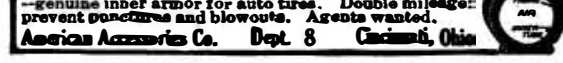

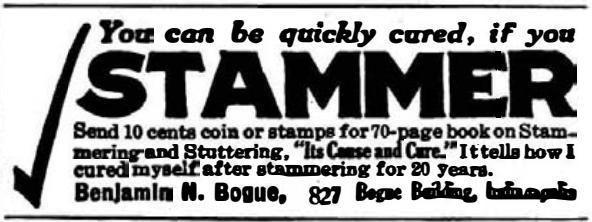

BANDY MAN'S WORKSHOP AND
LABORATORY
Compiled and edited by A. Russell Bond. 6x81/4
inches. Cloth. 467 pages. 370 illustrations, $82.25 ;$
by mail, \$2.40.
A compilation of hundreds of valuable sugges-
tions and ingenious ideas for the mechanic and
those mechanically inclined. The suggestions are
practical and the solutions to which they refer are
of frequent occurrence. It may be regarded as
the best collection of ideas of resourceful men
published.
SCIENTIFIC AMERICAN PUBuSHING CO.
woolworth Buiding New York


What Goes On Inside a Gas Cylinder $I^{T}$ is a simple matter to take an indicator card of a steam engine. The apparatus for doing this is familiar, and the principles upon which it is built and operated date back to the time of the immortal James Watt. Naturally, in the development of the gas engine, engineers wished to apply the indicator to this new prime mover; but the question of how to do it proved very formidable. An apparatus which functionell very well in an engine running from one hundred to two or three hundred revolutions a minute and usng pressures that rarely exceeded a maximum of two hundred pounds to the inch, could not be applied to he internal combustion engine, with its enormous maximum pressures, its wide range of pressure, and its speeds of revolution that run up to three thousand per minute or even more. The illustrations which accompany this article show a beautiful solution of the problem by the engineer whose name the Mfidgley Indi-
cator bears. We had the pleasure of seeing one of cator bears. We had the pleasure of seeing one of
these in operation recently at the laboratory of the these in operation recently at the

Dayton-Wright Airplane Company. of which is connected to the rotating parts of the engine, the other to the combustion chamber of one of the cylinders; the first giving a record of speed and the other of pressure and the two being ingeniously combined in their effect, through the medium of a beam of light, so as to produce a luminous indicator card.

Briefly stated, the luminous diagram is produced by means of a pencil of light and two movable mirrors, the first recording the changes of pressure, and the second the travel of the piston.

The system comprises a six-volt light bulb, $A$ which is used as the source of light; a motor box, 13, which is supported by a bracket, $C$, clamped to the cylinder to be tested; a concave rocking mirror, $D$ mounted above the cylinder, and a rotating mirror, $E$ which is in the form of an eight-sided prism and is which is in the form of an eight-sided

carried at the rear of the motor box.
The front of the motor box consists of a curved pan of frosted glass, $F$, upon which the diagrams are projected. At the back of the box and outside of it is the light bulb, $A$, above mentioned. $A$ beam of light passes through a small hole in the back of the motor box and falls on the concave mirror, $D$. From this mirror it is reflected back through the motor box to the eight-sided mirror, $E$, in the rear of the box, which eight-sided mirror, $E$, in the rear of the box, which
may be either oscillated or revolved, according to may be either oscillated or revolved, according to whether pressure-volume. or pressure-time cards are desired. The convergent ray of light is then reflected
from the eight-sided mirror and projected forwar upon the frosted curved glass, $F$, forming the front of the motor box.

The pressure-element consists of a small cylinder, $G$ and its piston. The lower end of the cylinder screws directly into the combustion chamber, the gases of

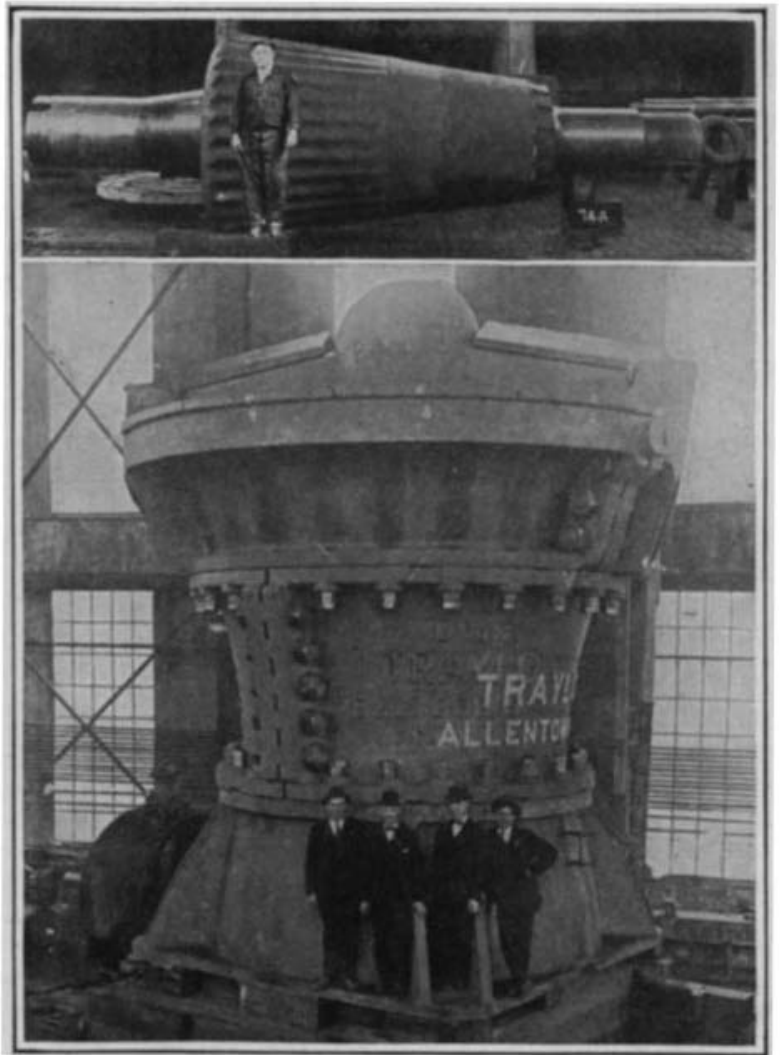

This huge stone crusher has a capacity of from 2,500 to 2,700 tons of stone an hour

which are free to pass into the cylinder. The pressure in the cylinder, $G$, raises its piston and compresses a resisting spring. This movement is transmitted through a vertical shaft to an arm which causes the curved mirror, $D$, which is mounted on the top of the cylinder, $G$, to rock on its horizontal axis and so change its vertical angle in proportion to the pressure on the piston. Thus, it can be seen that, as the pressure rises, so the Thus, it can be seen that, as the pressure rises, so the reflected beam of light will rise upon the octagonal mirror at the back of the box and conversely, with the
fall of the pressure, there will be a fall of the beam fall of the
of light.

The eight-sided mirror, $E$, at the rear of the moto hox is mounted on a vertical shaft, which is so geared that it rotates at exactly one-eighth engine speed. The movement of this mirror causes the beam of light to move to and fro across the curved glass front, $F$, of the motor box, which has been made ninety degrees in order that the beam of light focused and reflecterl (Continued on page 688 )

\section{A Giant Among Stone Crushers}

A HUGE stone crusher with a capacity of from 2,500 $A$ to 2,700 tons of stone per hour has recently been installed in a Michigan quarry. This stone crusher, which is said to be the largest in the world, has been the center of attraction for quarrymen ever since it ussumed its finished lines in the Pennsylvania machine works.

This large stone crusher, which is shown in the ac companying views, was built in ninety working days. Furthermore, despite its great weight and bulk, it was loaded on the cars, transported, unloaded and set up ready for work in fourteen days; a remarkable record, to be sure. The upper view, showing the revolving member which in conjunction with the stationary member does the crushing, weighs 65 tons.

\section{Measuring the Flow of Liquids}

TSTRUMENTS for measuring and recording the 1 flow of liquids have recently been brought out by a large British firm. In a description of these the curve deduced for the formula chosen to represent the flow of water over a weir or notch is cut on a drum in the form of a spiral or screw thread, the pitch of which increases from the zero end of the drum in correspondence with the increased rate of flow over the weir or notch as the depth of water increases. A float having a fine toothed rack attached to its spindle is placed the weir channel or in a chamber connected with it, and this rack engages with a union on the axle of the drum, so that the latter rotates as the float rises or falls. In cases where the depth of water exceeds about 12 inches a chain sprocket wheel is substituted for the rack and pinion. A pin attached to the end of a saddle arm engages with the screw thread and imparts a lateral motion to a slider bar carrying a pen, which is thus caused to move over a chart ertual distances for equal increments in the rate of flow. The proportionate diagram obtained in this way can be readily interpreted by the aid of the planimeter and the total volume of water passed in any given time determined. The beak of the saddle arm as it moves along the graduated spiral groove gives a magnifiet indication of the rate of flow, and a pointer attached to the float rod shows on a scale the actual depth of water in the weir.

In another form of the instrument an integrating arrangement is added; this counts up the total number of gallons or cubic feet passed, and the guintity can be read off directly from ordinary counting dials. These recorders, for which an accuracy within one per cent is guaranteed, are applicable not only to determining the flow of rivers and streams, but also to measuring the feed water to boilers and the condensate from engines and turbines, as a check upon steam consumption and the efficiency of the plant.

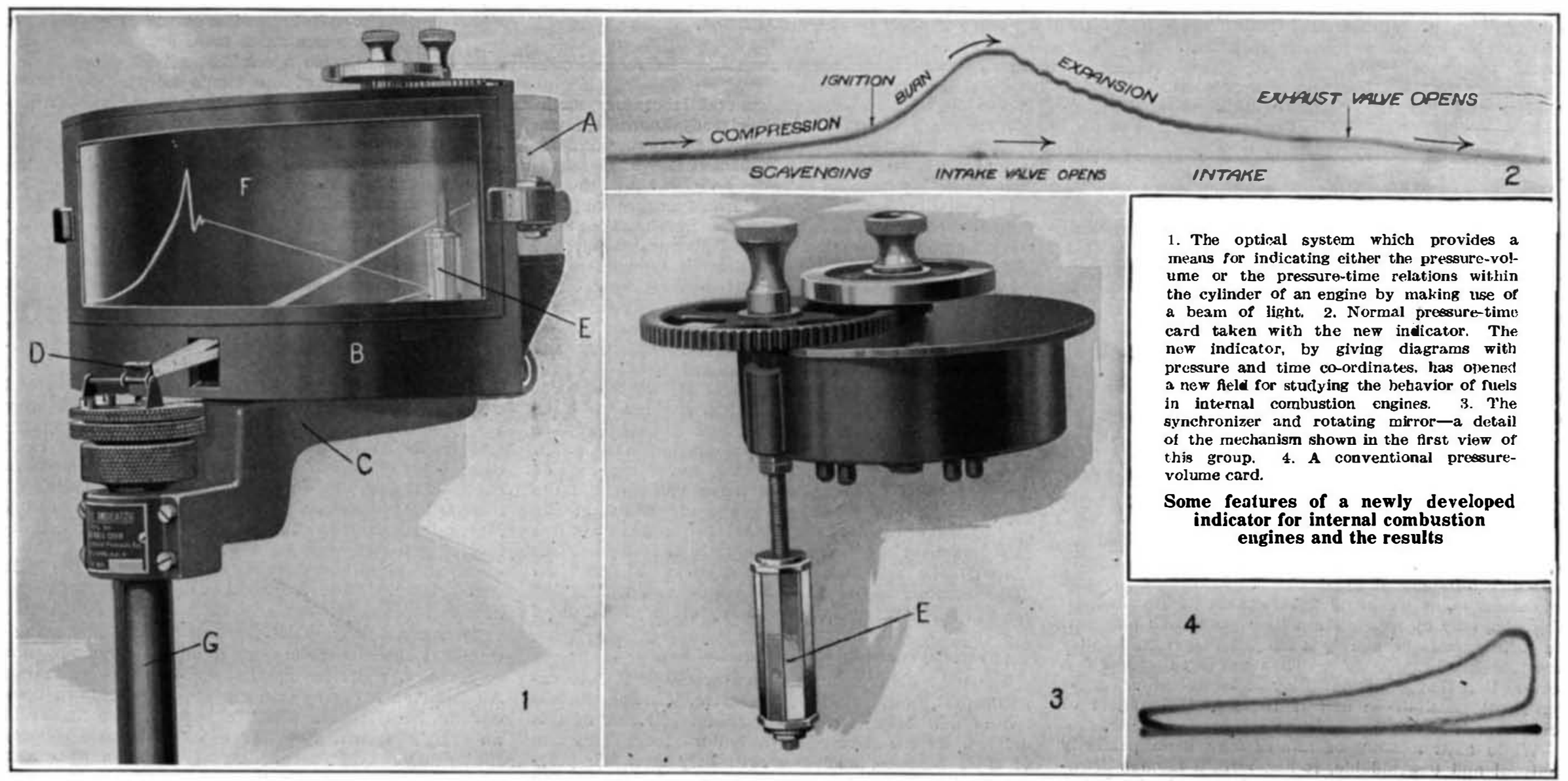




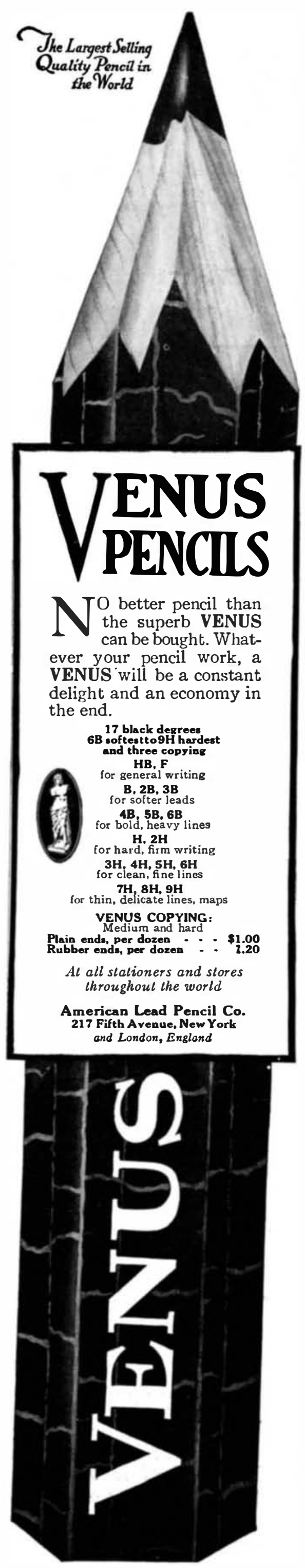

What Goes On Inside a Gas Cylinder The same amount of chemicals and cookmoved across the ground glass once quantity of pulp. The cost of allen for each revolution of the engine. the cotton stocks also is prohibitive and Just at the point where the beam of light it is doubtful if a sufficient supply could next succeeding face of the rotating mirror engages the beam of light and simultanernusly reflects it to the opposite end of the glass screen. In this way the pressure-time relations with the engine cylinler for two revolutions, or one cycle, are rendered visible on the ground gliss in the form of a pressure-time card.

It should be explained that, for taking pressure-rolume cards, a synchronizor is provided, which oscillates the eight-sided mirror within the motor box in synchro-
nism with the reciprocating motion of the engine piston.

We present two cards, one a conventional pressure-volume card, and the other a normal pressure-time card, both taken on a MIidgley Indicator.

The conventional indicator card shows the relations between pressure and vol ume in the engine cylinder; but the p:essure-volume card is not well adapted io making a study of the phenomena ocerr-
ring during the combustion in an internalcombustion engine. The reason for this is that ignition and combustion occur when the piston is close to top dead center, during which time the horizontal movement along the pressure-volume card
is so small that pressure changes are recorded merely as a single vertical line. The pressure-time card is preferable because the movement along the horizontal or time axis is always uniform, thus making pressure changes clearly distinguish-

Photographic indicator cards are obtained by holding a sheet of bromide paper against the glass front of the motor box. By pushing a button, the voltage of the light circuit is increased for ex-
actly two revolutions of the motor, and actly two revolutions of the motor, and photographic paper.

\section{What is Wrong with Our Paper} Supply?

\section{(Continued from page 674)}

the drive to prevent stretching the paper and tearing it as it passes through the machine. The difficulty has been met in several ways. One form of drive is by a train of gears, each gear being provided with a friction clutch to provide flexibility. Another form of drive is by rope pulleys. In either case there is a limit to the possible speed. A new form of drive has just been devised using synchronous motors with a special

mechanism to govern the speed.

The machine is divided into section and each section is driven by an individual motor. The speed of each motor is carefully adjusted and controlled to a
fine degree of accuracy by the special control mechanism. Recent installations control mechanism. Recent shown that it gives the mill an almost unlimited range of speed, permitting the machine to be run at all times at the highest speed the pulp will permit.

It is possible this invention will relieve, in some degree, the present shortage by speeding up existing mills which have
good pulp supply available. Wherever goosible paper mills have been located near water falls so that a supply of cheap near water falls so that a supply of cheap electric power is available, making the
motor drive most practical.

Woods similar to spruce, such as fir and pine, are sometimes used for pulp, but the resin in them fouls the machinery to such in extent as to halt operations frequently. Materials other than wood cannot be used economically in the sulfite process because of their light weight for the bulk involved. Thus cotton stock have been found to prodnce a good sulfite pulp but only one-fourth the weight of cotton stocks, as compared with spruce,
can be put in the digester at one time.

\section{be had.}

Experiments are being made now with species of snuthern grass, but the same jection alplies in the making of sulte pulp. It is possible, however, that substitute for ground wood will be developed from this or a similar source. Great quantities of the grass are availan our Florida swamps. But here is no coal or water near the grass supply and it takes nearly as much coal as pulp to produce a ton of paper. So it would probably be more economical to haul the rass to the present northern mills than to build new mills at the source of such supply.

Scientists at Columbia University are conducting a series of experiments with production of hook papers. Bamboo grows very rapidly in the tropics. so that paper mill located in the center of a amboo forest would have a perpetual supply by rotating its cutting operations,
with the plant as the center of a circle. with the plant as the center of a circle. There is good assurance of the
success of these experiments.

Bamboo pulp produces a fair quality of book paper and there is the possibility, s our knowledge of the methods of making bamboo pulp improve, that one day our paper industry will be transferred
largely to the tropics and that our newspapers will be printed on quality of paper equal to that now used in magazines. The paper may cost even less than ordinary newspaper, such as we know it now. Another angle of the problem in which a ittle work has been done is the reforestng of the lands devastated by our presnt mills.

Relief might come from still another source. As noted above, the chief reason many other woods cannot be used instead of spruce is because of the resin in them. Fir, for instance, has an appearance very similar to spruce, both in the tree and in the board, but it cannot be used, except o a limited extent, because of the resin it. If some economical method of extracting the resin could be found, fir
and other woods would be made available and the supply of raw material multiplied many times. This, however, seems rather forlorn hope.

In fact, with the exception of the new electric drive for paper machines, none of the possible remedies for the situation reviewed here offers hope for any immediate relief. The chief reason is the skepticism of the paper industry itself as to new schemes. Too many of them have already been tried with no results and any new method that finds general adoption will first have to be demonstrated by some venturesome soul in competition with the established methods of the industry.

But it is the history of invention that whenever a great need arises, there usually is found a way to meet it. It would ment for the introduction of some revo-
ment for lutionary idea or invention in the paper industry. Indeed, now that the problem is being tackled by real scientists in a serious way, it is not at all a wild guess that some way out of the "blind alley," in which the paper industry finds itself, will be discovered within the next few months or years.

Until some new material or method has ctually been demonstrated it would be worse than folly-almost suicide--to continue our course of cutting off our only source of raw material-spruce foreststhout reforesting.

As for the immediate future-the next year-there seems little chance of escape from the present paper shortage and possibly higher prices.

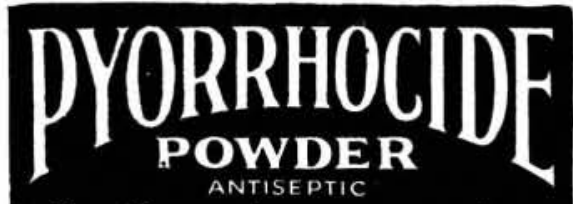

for Pyorrhea prevention

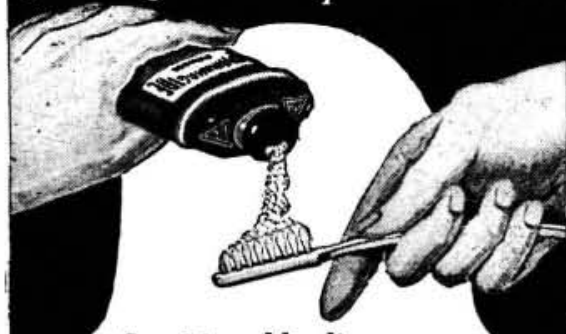

Sensitive, bleeding gums

are symptoms of pyorrhea - they lead to the loosening and the loss of teeth. Pyorrhocide Powder should be used. It is the one dentifrice that dental clinics, devoted exclusively to pyorrhea research and oral prophylaxis, have demonstrated to be beneficial in pyorrhea treatment and prevention. Dentists everywhere prescribe it.

scribe it.
It aids in repairing soft, bleeding, spongy, receding gums. It cleans and polishes the teeth. receding gums. It cleans and polishes the teeth.
To make gums firm and healthy, to keep teeth

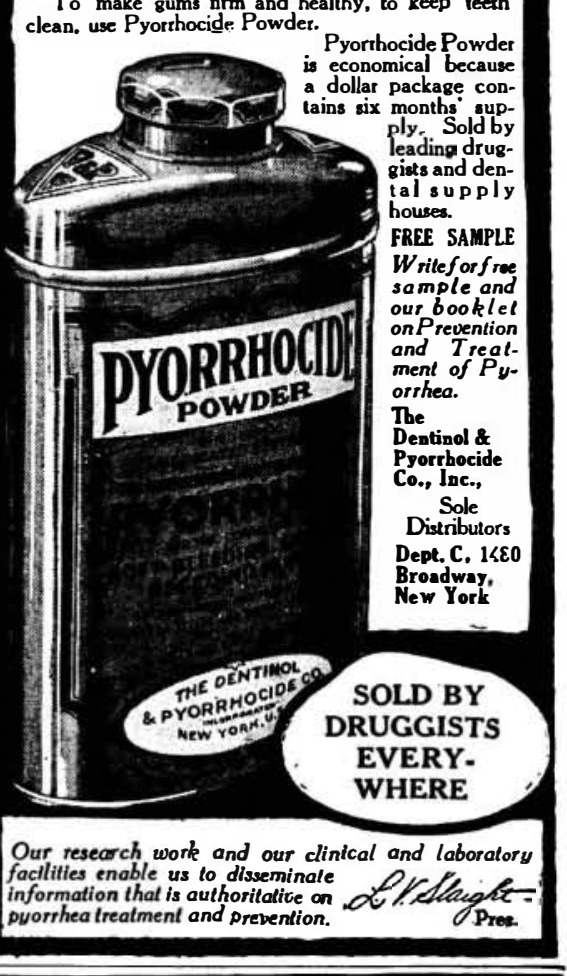

UNISOL BOILER PRESERVER

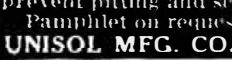
Jersey City, N. I

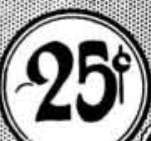

rUdes 300 172 AIRPLANE

Soars Gracefully and Does the Stunts of an

Expert Aviator

A scientific novelty of unusual interest. It will loopthe-loop, glide, spiral, pan-

Look1 cake-in fact, do al

Huke airplane.

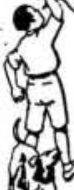
Every boy and girl
will want it! Be BFrst!
Get in your order now!
Sent prepaid by mall for
25c. Send starnpe. Cash
or Money order.

Globe Aiplane Co. 400 Globe Bullding
Nowark. N. J. 